\begin{tabular}{|c|c|c|}
\hline & \multicolumn{2}{|c|}{$\begin{array}{c}\text { SOSYAL ARAŞTIRMALAR VE YÖNETIM } \\
\text { DERGİII (SAYOD) }\end{array}$} \\
\hline & \multicolumn{2}{|c|}{ JOURNAL OF SOCIAL RESEARCH AND MANAGEMENT } \\
\hline E-ISSN: 2667-5897 & https://dergipark.org.tr/tr/pub/sayod & Paper Type: Review Paper, Makale Türü: Derleme \\
\hline Sayı:1, Nisan 2021 & Issue:1, April 2021 & $\begin{array}{l}\text { Received Date / Gelis Tarihi: } 28 / 10 / 2020 \\
\text { Accepted Date / Kabul Tarihi: } 17 / 12 / 2020 \\
\end{array}$ \\
\hline
\end{tabular}

\title{
USE AND MANAGEMENT OF PERSONAL PROTECTIVE EQUIPMENT IN PANDEMIES
}

Atıf/ to Cite (APA): Erdal, N. (2021). Use and Management of Personal Protective Equipment in Pandemies. Sosyal Araştırmalar ve Yönetim Dergisi, (1), 22-37

\author{
Nurgül ERDAL ${ }^{1}$
}

DOI: https://doi.org/10.35375/sayod.801661

\begin{abstract}
No matter how advanced the technology is, nature always reminds human beings of its unpredictable powers, and the natural environment in which we live may not create any warning or cause epidemics. Returning from the past to the future is likely to happen in the future, just as epidemics have been experienced in the past and the past. In pandemics spreading over a wide geography, personal protective equipment must be coded and managed correctly in order to be protected from the epidemic. Since pandemics develop suddenly, an environment of panic occurs and the people rush to an uncontrolled personal protective equipment and uncontrolled and unnecessary shopping is experienced at the beginning. It consists of scarcity as supply decreases and demand increases. It has difficulties in accessing personal protective equipment, including healthcare institutions. It's important that you didn't know, as they play an active role in preventing pandemics. In this review study, the supply of personal protective equipment, its effective and efficient use, the importance of proper disposal after use, its management, was applied correctly and appropriately. All countries in the world should be prepared against possible pandemics and should be learned through planning before pandemics occur. Since vaccination and treatment methods are not yet known at the beginning of the pandemic, personal protective equipment is extremely important.
\end{abstract}

Keywords: Pandemic, Personal Protective Equipment Management, Correct Use, Personal Protective Equipment

\section{INTRODUCTION}

Although it is not known precisely when the epidemic started, it is thought to be in the United States and also 16 centuries ago (Gendon,1994: 451).Pandemics are disease outbreaks that are widespread, mostly as a result of the spread of infection from person to person. In the globalizing world, when a new strain emerges, why do many people get sick and die because people have not yet developed immune systems. For example, Spain Flu (1918), Asian Flu (1957) and Hong Kong Flu (Rewar et al, 2015: 645) in the 20th century. Covid 19, which are currently seen, will continue to threaten the world in the future, as well as diseases such as AIDS, SARS, Ebola, Zika and other epidemics.

We are dealing with a huge pandemic these days when the world fairy is approaching 8 billion and we will face many new pandemics in the future. In the face of this situation, the insufficiency of social sharing, the health systems and policies of the country, the insufficiency

1 Dr, Istanbul University, Cerrahpasa Medical School, Hospital of School of Medicine, Istanbul, Turkey. nurgul.erdal@istanbul.edu.tr, ORCID ID: https://orcid.org/ 0000-0002-2961-3906 
of health institutions, triage practices, insufficiency of health personnel, increasing patient potential, the presence of ways of transmission, the increase of the world fairy, the difficulties in reaching the net, vaccine and personal protective equipment and not being extinguished factors are on the agenda (Üstün \& Özçiftçi, 2020: 151).

Pandemics affect individuals economically, culturally, psychologically, sociologically and have serious negative effects on the public ( Verikios, 2016:1225). Epidemics infect millions of people around the world, causing illness and widespread death in a large population. It is also a serious global threat. Short-term economic problems occur for the financial burdens, treatment costs, loss of production and indirect costs it causes. However, the country is under threat at its borders, and national security emerges as a problem. Schools that are closed in these processes, social and cultural life, tourism, agriculture and commercial activities, and investments cause great damages that are difficult to compensate (Özkoçak, 2020: 1193). That's why PPE is needed to prevent pandemics and reduce contagion.

Pandemic periods are periods in which various arrangements should be made for emergency response and contagion. These days, they organize various policies and take protective measures to reduce the epidemic. This is initially on a global basis. The right interventions that can be handled effectively and quickly during these periods ensure that people are protected from the disease, they are treated if they get sick, and their recovery rate increases. To have effective and efficient emergency management, to manage such crises well, learn the basics of combating the pandemic. In this case, it can be defined as a survival issue of both human health and economic continuity.

Good management of pandemics depends on taking protective measures. The important thing here is the correct management and use of personal protective equipment. To achieve this, training should be given for accurate information, accurate use, accurate control of the material and correct supply. The fact that all pandemics are a test and teaching for familiar people. Although these outbreaks give extra duties and responsibilities for administrators, scientists, health systems, all individuals are affected. It is essential to take vaccine protective measures against epidemic diseases, to pay attention to personal hygiene and cleanliness, the correct use of personal protective equipment and the necessary vaccine. Introduction of unique protective equipment pandemic for vaccination time display. It should be the duty of the pandemics to be protected from the epidemic and to comply with the necessary rules and procedures (Aslan, 2020: 41).

\section{PANDEMIA}

We can say that deaths from infectious diseases are more common than deaths in wars in human history. The death of millions of people from the past to the present may be the result of these radical changes in human life (Esen, 2017: 75). Today, pandemic words are used more than health and disease words. What is this pandemic? The fact that the infectious disease is a specific and epidemic, that this epidemic exceeds the continents, spreads to broad geography, begins to affect a large mass and even the whole humanity is a pandemic. Word pandemic for the first timey by British physician Gideon Harvey, in (1666 ). He used "Pandemick" interchangeably with "Epidemick".means a malignant disease and "concerns the country in general."Pandemic comes from the Greek language income pan, meaning "all." The infectious disease epidemic is known to affect an entire country or one or more continents. They state that pandemic strains undergo genomic mutations and tend to spread continuously ( 
Honigsbaum,2009:1939). Figure 1 shows the distinction between epidemic and pandemic in detail.

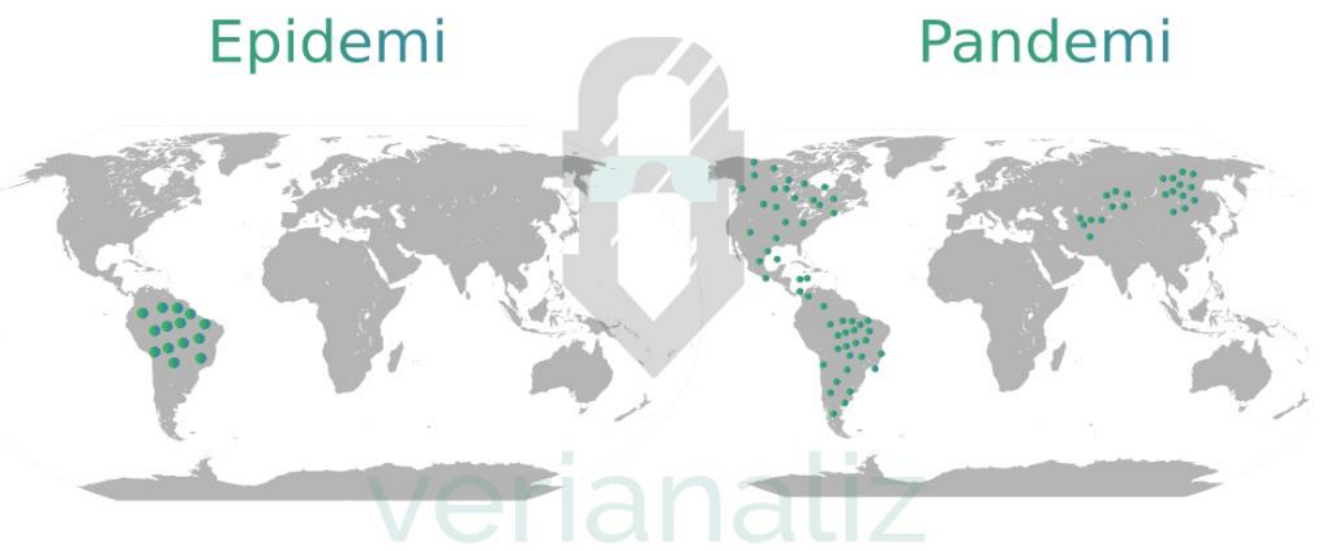

Figure 1: Difference between epidemic and pandemic.

Reference: (https://www.verianaliz.net/pandemi-tarihi-corona-covid19-veri-analiz infografik/\#endemianchor)

Although the pandemics seen around the world differ, they have some basic features (Qiu et al., 2017: 4). These;

1- Broad Geographic extensions and inter-regions are globally categorized. For example, Swine Flu has spread to a total of 178 countries when the H1N1 pandemic occurred in 2009 (Rewar et al., 2015: 646).

2- The disease moves from one place to another. For example, pandemics such as Black Death, Influenza, SARS, Covid-19 have been transported almost everywhere in the world (Qiu et al., 2017: 4).

3- In pandemics, the disease occurs as new or is variants of existing organisms. Only since the 1970s, more than one thousand five hundred new disease-causing pathogens have emerged, $70 \%$ of which are of animal origin. Although it is known that not all of these pathogens have turned into a major epidemic, the Ebola virus, which emerged in 1976, and HIV, which began to be seen since 1983, draw attention as a global problem on human health (World Health Organization $2018: 14$ ).

4-Global pandemics with high mortality and morbidity occur when a virulent new viral strain emerges for which the human population is not immune, and is severe (Rewar et al., 2015: 645). Violence is predicted by case fatality (Donaldson et al., 2009:5). "Unlike Ebola, most cases die within 10 days of the initial infection, and the disease has a mortality rate of 50-90\%. As of 30 May 2010, there have been deaths in almost 214 countries and more than 18,138 people around the world (Su \& He, 2015).

5- Pandemics manifest themselves with high attack rates and explosive spread. For example, influenza H1N1, Covid 19 and Ebolan are examples of pandemics. However, even if the 
epidemic is common, it will not be included in the pandemic list if it is not explosive. For example, although the West Nile virus, seen in 1999, spread to the Middle East, Russia and the Western Hemisphere, it was not considered a pandemic because the transmission was slow and the attack rate was low (Donaldson et al, 2009: 5)

6- Societies' immunity is very important in preventing pandemics. In other words, population immunity should be given importance to reduce the spread and transmission of the pandemic (Taubenberger \& Morens, 2009:15). For example, Covid 19 spread in a short time because it is the new form of the influenza virus (Karcioğlu, 2020: 55).

7- Pandemic diseases are contagious, can be transmitted from individuals to individuals or can be passed from vectors to humans.

WHO, an international organization, analyzes the risks in common diseases, warns countries about the measures to be taken and supports countries. It is important for public health and is the center of data flow. They make a certain amount of funding to protect against epidemics spread in countries. In Figure 2, we can see the funding of various countries. The USA allocates the highest amount of 115.8. (Million \$), followed by China with 57.4. (Million \$). Japan is below three China with \$41.0 Million). Germany 29.1. (Million \$), UK 21.9. (Million \$), France 21.2. (Million \$), Italy 15.8. (Million \$), lowest place Brazil 14.1. (Million \$) followed by $\$$ ). Necessary precautions should be taken in order not to be caught unprepared for pandemics. The use of personal protective equipment is an important method as no protective vaccine has been developed at the first stage. The management and use of personal protective equipment is a strategic situation during the pandemic. (https://www.verianaliz.net/pandemitarihi-corona-covid19-veri-analiz-infografi/\#endemianchor)

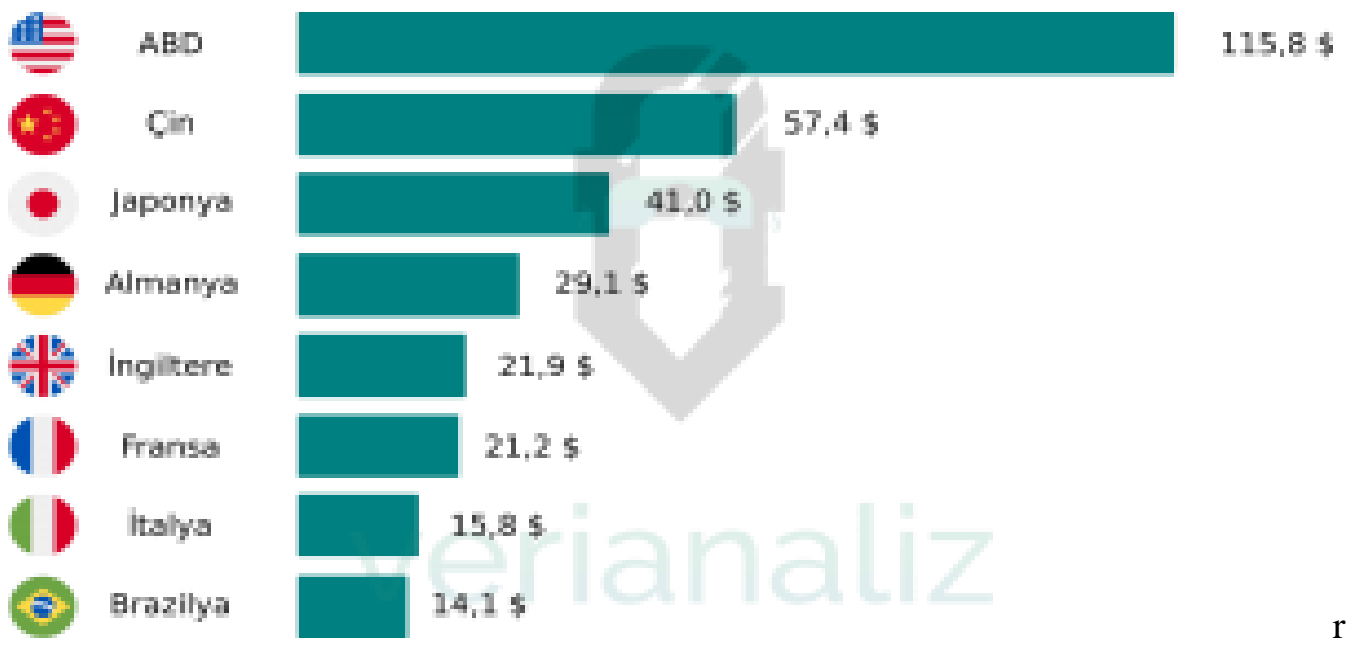

Figure 2: Funding made by countries to WHO as of March 31, 2020. (Million \$)

Reference: (https://www.verianaliz.net/pandemi-tarihi-corona-covid19-veri-analiz-infografik/\#endemianchor)

\subsection{Pandemic History}

Since the world has existed, people have faced many epidemics. Various pandemics have been encountered in the world at different times throughout history, causing the collapse of empires and intercontinental migration. Many major pandemics have been recorded in human history, 
including smallpox, plague, dengue virus, AIDS, influenza, severe acute respiratory syndrome (SARS), West Nile disease and tuberculosis. Flu outbreaks are unforeseen but recurrent events that can have serious consequences on communities around the world. Flu epidemics have occurred approximately three times each century since the 1500's. For example, in the 20th century, there were 3 flu epidemics called "Spanish Flu" in 1918-1919, "Asian Flu" in 19571958 and "Hong Kong Flu" in 1968-1969. Spanish Flu in 1918-1919, which killed more than 50 million people, was recorded as the most devastating epidemic in world history (Qiu, et al., 2017: 4).

Table.1. Pandemic History

\begin{tabular}{|c|c|c|c|}
\hline History & Pandemics & ACTIVE & DEATH NUMBER \\
\hline $165-180$ & Antonine Plague & $\begin{array}{l}\text { Could be chickenpox / } \\
\text { measles virus }\end{array}$ & 5.000 .000 \\
\hline $541-542$ & Justinian Plague & Yersenia Pepsis & $30-50.000 .000$ \\
\hline $735-737$ & Smallpox Japanese & Variola Majör Virus & 1.000 .000 \\
\hline $1347-1351$ & Black Death & Yersenia Pepsis & 200000.000 \\
\hline 1520 & New world smallpox & Variola Majör Virus & 56.000 .000 \\
\hline $1629-1631$ & Italia Plague & Yersenia Pepsis & $1.000,000$ \\
\hline 1665 & London Big Plague & Yersenia Pepsis & 100.000 \\
\hline $1817-1923$ & $\begin{array}{l}\text { Cholera Pandemia 1- } \\
6\end{array}$ & V.Cholera & 1.000 .000 \\
\hline 1885 & Third Plague & Yersenia Pepsis & $\begin{array}{l}\text { 12.000.000(China ana } \\
\text { India) }\end{array}$ \\
\hline Late $1800 \mathrm{~s}$ & Yellow Fever & Yellow Fever Virus & $100.000-150.000(\mathrm{ABD})$ \\
\hline $1889-1900$ & Russian Flu & Could be H2N2 Virus & 1.000 .000 \\
\hline 1918-1919 & Spain Flu & H1N1 Virus & $40.000 .000-50.000 .000$ \\
\hline $1957-1958$ & Asian Flu & H2N2 Virus & 1.1000 .000 \\
\hline $1968-1970$ & Hong Kong Flu & H3N2 Virus & 1.000 .000 \\
\hline 1981-Present & AIDS/ HIV & HIV & $25.000 .000-35.000 .000$ \\
\hline $2002-2003$ & SARS & Coronavirus & 770.000 \\
\hline $2009-2010$ & Swine Flu & H1N1 Virus & 200.000 \\
\hline $2014-2016$ & EBOLA & Ebola Virus & 11.000 \\
\hline 2015 Present & MERS & Coronavirus & 850.000 \\
\hline 2019 Present & Covid-19 & Coronavirus & $\begin{array}{l}994.000 \text { (26 Semptember } \\
2020)\end{array}$ \\
\hline
\end{tabular}

Reference: (http://www.yeditepehastanesi.com.tr/koronavirus-pandemisi-ilk-degil)

Table in the 1. some important pandemics have been seen in the world throughout history. Throughout history, humanity has faced many pandemics that caused diseases and deaths that spread widely. Some of the pandemics dating back to pre-Christ are not known because some are recorded and some are not. It is known that pandemics have shocking effects on human history. The pandemics that have affected the most since ancient times; We can count as Amvas Plague, Black Plague, cholera, Spanish Flu, AIDS, New World Smallpox Epidemic, Swine Flu, 
Ebola, SARS and MERS, Asian Flu and Hong Kong Flu and Covid-19. To briefly explain these silent killers;

Amvâs Plague: This plague is also known as black death. It is called by this name since it was seen in Amvâs near Jerusalem in 639. It has spread to a wide geography including Urfa, Damascus, Jordan and Palestine (Aslan, 2020: 36).

Black Plague: 1348 plague epidemic from the Asian continent to the European continent via Sicily. It is an epidemic in the past with extremely important consequences. It has various types and the exact cause of its occurrence is unknown. Various treatments and prevention to treat the disease roads have been developed, but still, in this epidemic nearly half of them died. At the same time, riots, change in the demographic map of the continent, psychological insecurity and fear. The emergence of the social environment, the weakening of social relations, various persecution of the Jews, stagnation of trade, expensive and cultural consequences. With are encountered ( Genç,2011:124).

Cholera: Cholera, which was known as a local disease in India until the 19th century, spread out of the region at the beginning of this century, causing huge pandemics and took thousands of lives. he was. East-West world of cholera. Iran and the Ottoman geography between the two countries were highly affected by this pandemic. It has spread to the new world through Europe (Y1lmaz,2017: 51-52).

Spanish Flu: It is an epidemic between 1918-1920. In these years, the world population is less than 2 billion and one third of the population has this disease. The First World War continues in these years. It is estimated that nearly 50 million people died from this epidemic and it is known that there are more than those who died in the war (Eşidir \& Bak,2020: 11).

AIDS, HIV: Human acquired immunodeficiency syndrome (AIDS) is caused by two lentiviruses, human immunodeficiency viruses types 1 and 2 (HIV-1 and HIV-2). Both HIVs consisted of multiple cross-species transmission of monkey immunodeficiency viruses that naturally infect African primates (Sharp \& Hahn, 2020,1). It is an infectious disease that causes the immune system to collapse in humans. By affecting the immune system, it lowers body resistance, makes it vulnerable to various diseases and eventually causes death. It is a sexually transmitted disease.

New World Smallpox Outbreak: It is a smallpox disease seen between 1520-1902. When Europeans first came to the New World from the Old World in the 15th century, they brought along a series of new diseases. Variola (smallpox) virus, with its microbiological, genetic, antigenic and epidemiological features, can be considered as a potential biological weapon and is a potential danger various flower outbreaks occurred and it was destroyed in 1979 ( Ristonovic et al., 2016: 587).

Swine Flu (H1N1): It was first seen in Mexico in 2009-2010. The causative agent was H1N1 virus and it spread rapidly and infected Pandemic influenza A (H1N1) 2009 virus The most important feature of the infection it causes is that it can cause severe infection in young adults and patients without risk factors ( Selvi Can, et al., 2010:9).

Ebola: Ebola virus causes severe hemorrhagic fever in humans and has a high mortality rate. 2013--2016 outbreak in West Africa, on an unprecedented scale, it caused an outbreak greater than any previous outbreak, with 28646 reported cases and 11323 deaths ( Coltart et al., 2017:1). 
SARS: Human coronaviruses (HCoVs) were previously known as harmless respiratory pathogens. It gained importance after the severe acute respiratory syndrome (SARS) epidemic and the emergence of the Middle East. It spread from the southern china market in 2002. 29 countries infected 916 deaths and 8000 people ( Y1n \& Wunderınk, 2018:130).

MERS: Middle East respiratory syndrome (MERS), CoVs were the pathogens that caused respiratory tract infection. MERS, which was first seen in Saudi Arabia in 2012., it resulted in 720 near deaths in 27 countries ( Yin \& Wunderınk, 2018:130).

Asian Flu (1957-1958) and Hong Kong Flu: Asian influenza A (H2N2) strain and Hong Kong The influenza A (H3N2) strain caused the 1957 and 1968 outbreaks, respectively. Both strains of viruses first appeared in China (Hsieh et al., 2006:2). The H2N2 virus, which was thought to be caused by the mutation of the Influenza-A virus in ducks between 1968-1970, was reported in East Asia approximately 40 years after the Spanish Flu. This virus, which spread all over the world in a short time and caused the pandemic, caused the death of approximately 1.1 million people .

Covid-19: First appeared in Wuhan (Hubei, China) in December 2019 with a diagnosis of pneumonia and the new coronavirus was identified as Covid 19. On January 30, 2020, the World Health Organization declared a pandemic. Covid-19, which is still in effect, continues to be economically, socially, psychologically and culturally destructive all over the world (Zheng et al, 2020: 259).

\section{Use Of Personal Protective Equipment (Ppe)}

In the globalizing world, the use of PPE in the prevention of epidemics and pandemics is an extremely important issue. Although advances in the diagnosis and treatment of diseases in the technological age are promising, the size of the epidemic and pandemic is increasing due to the increase of the world population, industrialization, crowded cities and economic insufficiencies.

Developed countries have focused on the diagnosis and treatment of noncommunicable diseases rather than communicable diseases. In third world countries, the fight against infectious diseases continues. While noncommunicable diseases continue to increase in the world, many pandemics have been observed in the 21st century. SARS, a member of the Coronovirus family, was seen in Asia and Canada in 2002-2003 and caused the death of 779 people. In 2009, 14,286 people died in the Swine Flu (H1N1) pandemic. Another Coronovirus, MERS, occurred in 2012 and thousands of people died. A large number of people have lost their lives due to COVID-19, which is currently in effect. As it can be understood from all of these, we are faced with consequences that cause the death and illness of thousands of people, as the necessary importance is not given to preventive health services. When protective measures are followed and proper procurement and use of PPE is provided, pandemics can be prevented and overcome with less damage (https://www.teb.org.tr).

The most effective method in preventing pandemics is the appropriate and appropriate use of personal protective equipment. Today, with the understanding of the importance of occupational health and safety and the enactment of the law numbered 6331, personal protective equipment has started to be mentioned. The subject of personal protective equipment is included only in articles 19 and 26 of the Occupational Health and Safety Law No. 6331. According to Article 19 , employees are obliged to use and protect the personal protective equipment provided to them correctly. In Article 26, it is stated that enterprises are required to provide personal 
protective equipment in accordance with the standards and CE marked, otherwise they will pay administrative fines ( https://iscidunyasi.com/kisisel-korguard-donanim-nedir).

Choosing the appropriate PPE at workplaces and ensuring its correct and appropriate use imposes responsibilities on both employers and employees. Employers' responsibilities are as follows;

Dangerous assessment and risk analysis of workplaces,

Determining and procuring suitable PPE for employees at work,

Training on proper and correct use and maintenance of PPE,

Replacing the PPE if it is damaged or worn, periodically examining, updating and evaluating the effectiveness of the PPE are among the responsibilities we can count ( Transfered Beşer \& Topçu, 2013: 241).

Employees' responsibilities;

-Use PPE properly and ensure proper cleaning and waste after use,

- Participating in trainings about PPE,

- Notifying the necessary places when KKE change and repair is required (Transferred, Beşer \& Topçu, 2013: 241)

Especially during the pandemic, employees are responsible for following the rules to be followed in the pandemic and attending information meetings. Three things affect the choice of PPE. These;

1- Type of exposure: It is important to choose PPE to be taken precautions against spillage, splash, spray, etc. that may form body fluids, blood, droplets etc. that may penetrate the clothing or the environment. One or more PPE can be used. In other words, the isolation method applied to the patients determines this situation.

2- It is the suitability and robustness of PPE: The PPE selected in this article must be suitable. For example, protective aprons are waterproof, liquid-resistant.

3- Suitability: It should be suitable for personal use. For example, it should be in the appropriate size to protect the workforce (Beşer \& Topçu, 2013: 241).

Healthcare workers are the most affected by the SARS 2, Ebola 3, MERS-CoV 4.5, Covid 19 pandemic, which have been seen in the last century and have very serious consequences (Enli, et al., 2020: 289). In pandemics, it is especially important for healthcare professionals to access appropriate personal protective equipment of appropriate quality and in sufficient number. Since healthcare professionals are at the forefront of pandemics, they must use personal protective equipment in the provision of healthcare services in order to fulfill their duties and protect the health of the society. Doctors, nurses, caregivers and other healthcare professionals working in health institutions come face to face with both physical and psychological risks in pandemics. If they have enough protective equipment they will feel safe. The most commonly used PPE in pandemics are gloves, gowns, masks, respirators, goggles, and visors. It differs in the material used according to the type of pandemic. PPE should be selected according to the functions performed (Beşer and Topçu, 2020: 241). 
PPE is very important in reducing and preventing pandemics. In the $2009 \mathrm{H} 1 \mathrm{~N} 1$ pandemic, we see the material used in three hospitals in Canada. and material usage. Mask use increased by $110 \%$ and $196 \%$ and respirator use increasedby $60 \%$ and $107 \%$, compared with the 2009 influenza season and the weeks $27-51$ in 2008, respectively. A ratio of 3 masks to 4 respirators was observed (Figure 3).

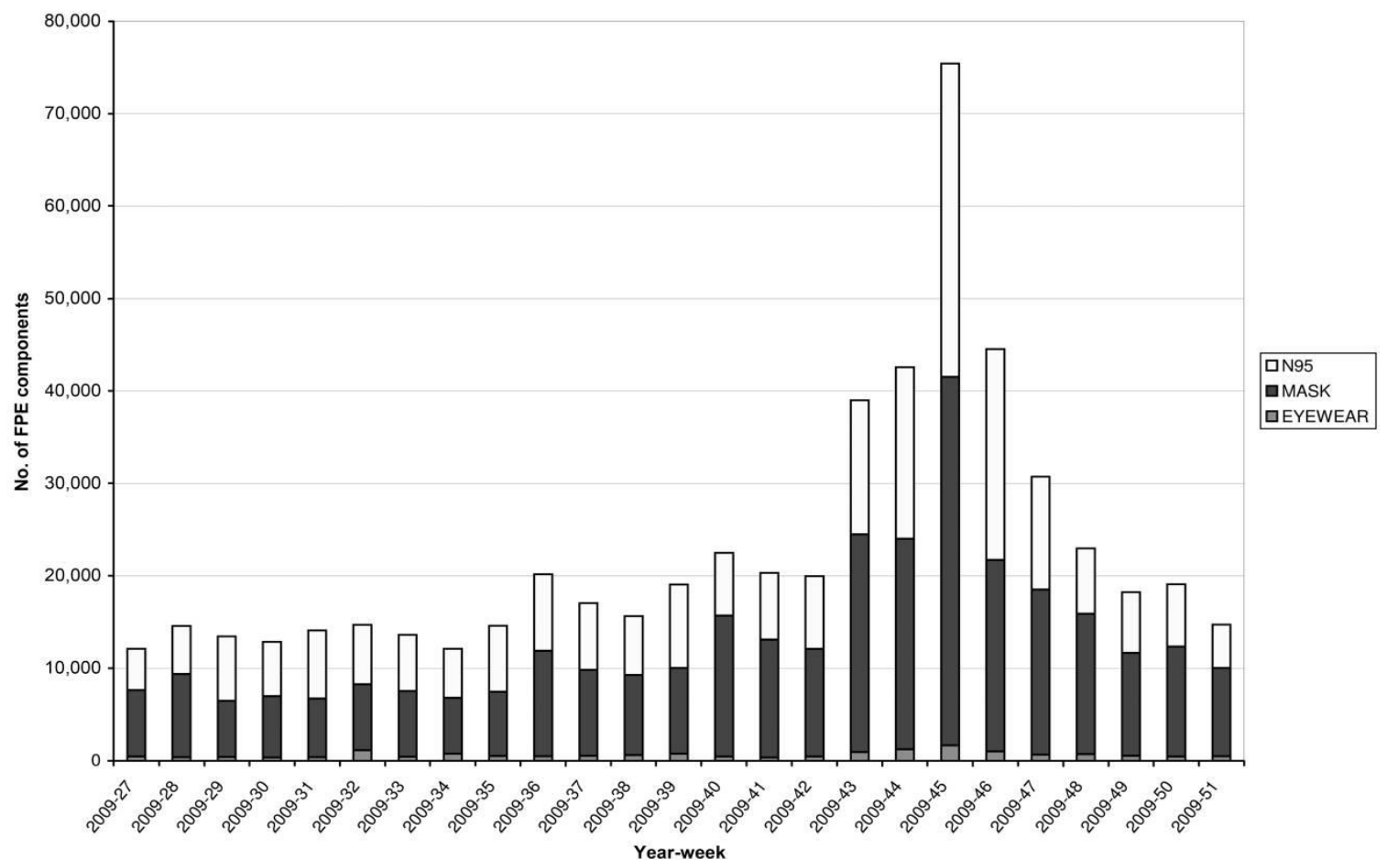

Figure.3. Pandemic (H1N1) 2009 Virus on Personel and Use of Facial Protective Equipment in

Reference: (Muray,M., Grant,J., Bryce, E., Chilton, P., \& Forrester,L.( 2010). Facial Protective Equipment, Personnel, and Pandemics: Impact of the Pandemic (H1N1) 2009 Virus on Personel and Use of Facial Protective Equipment infection control and hospital epidemiology october 2010, vol. 31, no. 10: 1011-1016 DOI: $10.1086 / 656564)$

KKE in pandemics shortcomings (for example, masks, gloves, aprons) endanger patients and healthcare workers. In the 2019 Covid -19 pandemic, KKE has experienced problems almost all over the world. USA needs were determined and deficiencies tried to be resolved throughout the country. ( Gondi et al.,2020: 90).

In the selection of PPE, the organs that are at risk of damage to the body should be taken under protection had to. The way to prevent pandemics is to protect all employees as well as healthcare workers. In the globalizing world, the pandemic can only be resolved if all nations produce solutions together. All countries of the world should help countries with missing PPE and the crisis should be resolved. In order to prevent pandemic, the correct use of PPE, the duration of use, the need for use, distribution according to risk groups, and efficient and efficient use should be done with scientifically accepted calculations.

\section{Management of Personal Protective Equipment}

Pandemics affect people physically, mentally and socially. Experts examining pandemics have stated that panic situations occur during these periods. Uncertainties about pandemics, concerns 
are increasing because of what the future will be and how long it will last (Consultant et al, 2020:390). In these panic situations, citizens attack PPE and unnecessary and improper use occurs. Citizens can be raised with information by the authorities. Pandemics can only be broken with meticulous and followed precautions. First of all, it is extremely important that individuals contribute and comply with the measures and decisions to be taken by the governments all over the world with great devotion (Özkoçak, 2020:1192).

Studies show that in the globalizing world, people will encounter a wide variety of epidemics and will affect people all over the world. However, it cannot be predicted when and from what source the epidemic will occur. Determining the severity of these epidemics will determine how political decision-makers will manage this situation and which management tools they will use (Budak \& Korkmaz, 2020: 75). Since technological advances were less in pandemics in the past, societies and countries were affected due to difficulties in communication, censorship practices, difficulties in accessing healthy information, people and institutions, inadequacy of opportunities to cope with the pandemic (Kırık, 2020: 38). In this period, infection control teams and infectious diseases physicians (PPE) should give brief information about hand hygiene and share the updated epidemiological characteristics of the disease are useful practices in preventing the pandemic (Kutlu, 2020: 331).

It is thought that pandemic management will be easier in the technological age. However, the density of the population, urbanization, environmental pollution, etc. may adversely affect the proper use of PPE and the rules to be followed. As understood from the recent COVID-19 pandemic, the rapid increase in the number of patients, the acceptance of patients above the available facilities, the insufficiency of the healthcare professionals, the insufficiency of the tools and equipment used cause the pandemic to increase and its duration. In order to prevent these negativities, all citizens should be taught the effective and correct use of personal protective equipment. In addition, healthcare workers should be screened and studies on this subject should be planned (Uğraş Dikmen et al, 2020: 35).

Pandemics are included in the dangerous and epidemic diseases group in disaster management (Erkal \& Değerliyurt, 2009: 150). For example, Coronavirus (Covid-19) indicates a disaster situation for societies because it is defined as a pandemic by the World Health Organization. Strategic pandemic management should be evaluated in terms of health and economic aspects affecting people's lives (Yetgin, 326: 327). KKE management consists of the following 4 stages. These (Who, 2020:2).

1) Minimizing the need for PPE: Planning of patients and jobs, triage applications, determining urgent procedures, planning beds and employees for the need for patients, beds and intensive care, and utilizing information and communication techniques as much as possible reduce the need to a certain extent. In addition, the follow-up of patients and barrier applications are important factors in reducing the need before coming to the hospital (Who, 2020:2).

2) Ensuring the correct and appropriate use of PPE: PPE use exposure It should be used according to the risk and transmission dynamics of the pathogen. Access to PPE will be difficult due to excessive demand and shortage of supply in excessive use. PPE varies according to functions. PPE selection and correct use should be provided according to the contamination risk in pandemics. Guidelines should be prepared according to the type of pandemic. For example, the Ministry of Health has prepared a 2019 (COVID-19) guide for the Correct Use of Personal Protective Equipment for Coronavirus Disease. The World Health Organization (WHO) stated 
that "the protection of health workers is the responsibility of managers" and workplace managers should ensure the appropriate and correct use of PPE,

3) Coordinating the PPE supply chain: The management of PPE should be coordinated with national and international supply chain management mechanisms: The following measures should be taken for this.

- Using PPE estimation methods based on accurate count models to ensure the efficiency of the requested materials;

- Monitoring and controlling PPE requests from countries and large response teams;

- Encouraging the use of a centralized demand management approach to prevent duplication of stocks, controlling inventory management, taking measures to prevent waste, and strict adherence to basic stock management rules. In addition, companies across the country must begin to work quickly to make the supply chain produce personal protective equipment to be provided to hospitals and healthcare professionals to overcome the wide-ranging impacts of the pandemic must utilize the full supply chain capacity. The company's worldwide supply chain teams must collectively strive to support countries and communities (https://satinalmadergisi.com/kayit-ol)

4) Optimizing PPE usability: It is necessary to make various plans to optimize PPE, use it in the best way, obtain better efficiency and manage it systematically. These: Monitoring and controlling the distribution of PPE in healthcare facilities, distribution and monitoring in other locations includes the rational use and distribution of PPE products from countries affected by pandemics and to be sent to the affected countries. Healthcare workers should be assigned in the fields they are trained in and should be given adequate training before being assigned. Measures to reduce employee risks should be taken by the institution, which are constantly revised within the framework of new epidemiological developments ( Bayraktaroğlu \& Fidan,2020: 49).

In order to ensure rational personal protective use behavior, it is very important to select and supply the right personal protective materials according to the risks of the working environment, to use them appropriately, to increase their interest and sensitivity, and to encourage employees to act correctly in terms of safety. The rational use of PPE is defined as the "correct" management at every stage of the process from the production of equipment to disposal of waste after use. PPE has an important place among the health expenditures of the countries. It is an important health problem for both developing countries and all countries and has a significant share in health expenditures. Since it prevents disease and carriage, it reduces health expenses when used correctly. Irrational PPE causes the material not to be used effectively and efficiently, decreasing resources, increasing waste and being contaminated.

\section{CONCLUSION}

In a globalizing world, fighting the pandemic is not the war of a single individual, a single society, a single country. Fighting the pandemic can only be achieved by joining forces of all segments of society. Lower segments of society and colonial societies are more affected by the pandemic. This can only be solved through development and solidarity. Many countries will be successful in preventing the pandemic by sharing information, providing resources, vaccines, drugs, materials and global solidarity. 
When pandemics emerge, an atmosphere of chaos occurs and the panic level of the public rises. Therefore, it becomes difficult to control misguided information. Authorities should raise the awareness of the public with the information they obtain from reliable sources. Various information and training should be given to ensure proper use of PPE and compliance with hygiene rules in order to prevent infection, the public should be provided with proper access to PPE, and those with inadequate financial status should be given necessary support to access PPE. usinesses can reduce contagion by taking various measures. They should replace the old work order with a new one. For example, in order to be protected from COVID 19, environments that can work at a distance of at least 1:50 - 2:00 meters should be prepared by paying attention to social distance. Employees should definitely use masks; even in the working environment, it should be mandatory to wear a mask, the management should provide masks to the employees, the fever of the employees should be measured when entering the business, and the units should definitely be placed with a disinfectant, the common areas should be cleaned frequently, when the work is over, the working environment should be disinfected (Özdemir,2020: 191)

Within the scope of preventive health services, procedures for accessing, using and disposing of PPE should be developed, and its distribution and implementation should be supported by laws. It should be given free of charge to citizens and countries with low financial status. In order not to be caught unprepared for pandemics, the correct use of PPE, its duration of use, the need for use should be determined, and distribution and effective use should be planned according to risk groups. Apart from routine use, sufficient materials for at least 3 months should be provided in institutions.

Proper procurement, proper use and use of PPE during pandemic periodssuitable protection recommendations (Bauchner, et al., 2020:1913).

1-During pandemic periods, purchases can be made from international suppliers, as there may be a decrease in production.

2- Materials can be taken back from dentists, farmers, universities, high schools, veterinary clinics, beauty studios, clean labs, etc.

3-Developing legal bases for general and private buybacks

4-Public or private awards related to PPE

5- Development of PPE suitable for reuse

6- Extending the supply

7- When necessary, you can use the protectors used in sports activities, etc., such as facials, eye protection, adhesive tapes, motorcycle helmets, etc.

8-Procurement of PPE to individual healthcare workers through charitable behavior in towns and communities.

9- Heat (for example autoclave), UV, ozone, ethylene oxide, hydrogen peroxide, bleach, isopropyl alcohol, gamma or e-beam radiation, microwave, copper sulfate, luminous methylene blue, sodium chlorine, iodine, zinc oxide impregnation (apron), hypochlorous acid, commercial using disinfectants such as laundering (for fabric). 
10- Reduce unnecessary services, cancel elective and outpatient procedures; reduce patient contact

11- Benefit from mobile and out-of-room monitoring and device controls, e-consulting, longterm residency IVs, blending of drugs or organize self-management, barrier visits.

12- Reduce student and trainee patient contact

13- use non-human services

14- Implementing decontamination protocols

15 -Group patients according to risks, ana classify use according to patient risk.

16-Determine the employees with good immune system and employ these employees in this process.

17- Use government solutions.

18- Reduce bulk packaging, Pyxis-like controlled distribution, reduce non-governmental regional coordination of PPE distribution.

\section{REFERENCES}

Aslan, R. (2020) Tarihten Günümüze Epidemiler, Pandemiler ve Covid-19. Ayrıntı Dergisi, 8(65): 35-41. http://dergiayrinti.com/index.php/ayr/article/view/1353/2383

Bauchner, H., MD; Phil B. Fontanarosa,P.B., \&Livingston,E.H. ( 2020).Conserving Supply of Personal Protective Equipment-A Call for Ideas, JAMA May 19, 2020, 323( 19): 1912-1914

Bayraktaroğlu,T., \& Fidan,E( 2020). Kriz ve Pandemide Hemşirelik Hizmetleri Önerileri Med J West Black Sea 2020;4(2): 44-50 DOI: 10.29058/mjwbs.2020.2.2

Beşer, A., \& Topçu, S. (2020). Sağlık Alanında Kişisel Koruyucu Ekipman Kullanımı, Dokuz Eylül Üniversitesi Hemşirelik Yüksekokulu Elektronik Dergisi, DEUHYO ED 2013,6 (1): 241-247 http://www.deuhyoedergi.org

Budak, F., \& Korkmaz, Ş. (2020). COVID-19 Pandemi Sürecine Yönelik Genel Bir Değerlendirme: Türkiye Örneği. Sosyal Araştırmalar ve Yönetim Dergisi, (1): 62-79. https://dergipark.org.tr/en/download/article-file/1107760

Coltart CEM, Lindsey B, Ghinai I, Johnson AM., \& Heymann DL. (2017) The Ebola outbreak, 2013- 2016: old lessons for new epidemics. Phil. Trans. R. Soc. B 372: 20160297. http://dx.doi.org/10.1098/rstb.2016.0297

Donaldson, L. J., Rutter, P. D., Ellis, B. M., Greaves, F. E., Mytton, O. T., Pebody, R. G., \& Yardley, I. E. (2009). Mortality from pandemic A/H1N1 2009 influenza in England: public health surveillance study. BMJ, b5213.BMJ 2009; 339 doi: https://doi.org/10.1136/bmj.b5213 (Published 10 December 2009)Cite this as: BMJ 2009;339:b5213 
Erkal, T., \&Değerliyurt, M. (2009).Türkiye'de Afet Yönetimi, Doğu Coğrafya Dergisi, 14 (22):147- 164.

Esen A. (2017). Sıhĥ̂-İ İctimâî Coğrafya Kitaplarına Göre İç Anadolu'da Görülen Salgın Hastalıklar (1922-1926). Ankara Üniversitesi Türk İnkılâp Tarihi Enstitüsü Atatürk Yolu Dergisi. 60: 73-90, https://dergipark.org.tr/tr/download/article-file/731121

Eşidir, O.V., \& Bak,G. ( 2020). Geçmişten Günümüze İspanyol Gribi’ne Türkiye'den Bakış Iksad Publications ,Ankara

Genç, Ö.(2011). Kara Ölüm: 1348 Veba Salgını ve Ortaçağ Avrupa'sına Etkileri, Tarih Okulu, 10: 123-150. https://d1wqtxts1xzle7.cloudfront.net/35532140/2008672644_13

Ghendon, Y (.1994). Introduction to pandemic influenza through history, European Journal of Epidemiology 10 ( 4): 451-453, https://www.jstor.org/stable/pdf/3520976

Gondi, S., Beckman,A.L., Deveau,N., Raja,A.S., Ranney, M.L.,\& Popkin,R. ( 2020): Personal protective equipment needs in the USA during the COVID-19 pandemicPublished Online May 14, 2020,90-91 https://doi.org/10.1016/

Hsieh, Y,C., Wu,T.Z., Liu, D.P., Shao,P.L., Chang,L.Y., Lu,C.Y., Lee,C.Y., Huang, F.Y.,\& Huang,L.M. ( 2006). 4 Influenza Pandemics: Past, Present and Future, J Formos Med Assoc, 105 ( 1): 1-6, https://pdf.sciencedirectassets.com/

Honigsbaum,M.(2009).Pandemi,the Lanset,373

(9679): 1939https://www.thelancet.com/action/showPdf?pi

Karcıoğlu, Ö. ( 2020).COVID-19: Epidemiyolojik bilgilerimiz ve hastalığın dünyadaki gidişi Journal of ADEM 1(1):55-71 https://dergipark.org.tr/en/download/article-file/1082681

Kırık, M., Altıntaş Var,S.S. ,Özkoçak,V.,\& Darıcı,S (2020).Pandemi Dönemlerinde İletişim Ve Alg1 Yönetimi: Yeni Koronavirüs Hastalığı (Covıd-19) Örneği Akademik Sosyal Araştırmalar Dergisi, 8( 104): 36-57 ISSN: 2148-2489 Doi Number: http://dx.doi.org/10.29228/ASOS.4324

Kutlu, R. ( 2020).Yeni Koronavirüs Pandemisi ile İlgili Öğrendiklerimiz, Tanı ve Tedavisindeki Güncel Yaklaşımlar ve Türkiye'deki Durum, TJFMPC, 2020;14(2): 329-344. DOI: 10.21763/tjfmpc.729917 https://dergipark.org.tr/tr/download/article-file/1094124

Muray,M., Grant,J., Bryce, E., Chilton, P., \& Forrester,L.( 2010). Facial Protective Equipment, Personnel, and Pandemics: Impact of the Pandemic (H1N1) 2009 Virus on Personel and Use of Facial Protective Equipment infection control and hospital epidemiology october 2010, vol. 31, no. 10: 1011-1016 DOI: 10.1086/656564

Qiu, W., Rutherford.S., Mao,A., \& C. Chu (2017). The Pandemic and its Impacts. Health, Culture and Society. 9-10: 3-11. (2016-2017) | ISSN 2161-6590 (online) DOI 10.5195/hcs.2017.221 | http://hcs.pitt.edu

Özdemir, L. (2020). 21.Ünite: İşletmelerde Koronavirüs Kriz Yönetim Stratejileri, Editör ( Aylaz,R ve Yıldız,E ) Yeni Koronavirüs Hastalı̆̆ının Toplum Üzerine Etkileri Ve Hemşirelik Yaklaşımları, ISBN: 978-605-7853-43-1, Malatya Üniversitesi Yayın evi 
Özkoçak, V., Koç, F.,\& Gültekin T. (2020). Pandemilere antropolojik bakış: koronavirüs (covid-19) örneği, Turkish $\quad$ Studies, 15(2), 1183-1195. https://dx.doi.org/10.29228/TurkishStudies.42679

Rewar, S., Mirdha, D., \& Rewar, P. (2015). Treatment and Prevention of Pandemic H1N1 Influenza. Annals of Global Health 81(5): 645-653. doi: http://dx.doi.org/10.1016/j.aogh.2015.08.014

Ristanovic,E., Gligic,A., Atanasievska,S., Protic-Djokic,V., Jovanovic,D.,\& Radunovic,M.( 2016). Smallpox as an actual biothreat: lessons learned from its outbreak in exYugoslavia in 1972, Ann Ist Super Sanità 2016, 52( 4): 587-597, DOI: 10.4415/ANN_16_04_21

Selvi Can, Ö., Ünal,N., Memikoğlu, O., \& Tulunay,M ( 2010 ). Pandemik İnfluenza A (H1N1) 2009 Virüsü ve Klinik Tecrübemiz, Yoğun Bakım Dergisi;9(1):1-12 www.yogunbakimdergisi.org/managete/fu_folder

Sharp,P.M.,\& Hahn,B.H. (2020).Origins of HIV and the AIDS Pandemic, Downloaded from http://perspectivesinmedicine.cshlp.org/ on December 10, 2020 - Published by Cold Spring Harbor Laboratory, 1-28

Su, W., \& He, H. (2015). Emergence and Pandemic Potential of Avian Influenza A (H7N9) Virus. Microbiology In Agriculture And Human Health, 33. DOI. 10.5772/61007. https://www.intechopen.com/books/microbiology-in-agriculture-and-humanhealth/emergence-and-pandemic-potential-of-avian-influenza-a-h7n9-virus

Taubenberger, J. K \& Morens, D. M. (2009). Pandemic influenza - including a risk assessment of H5N1. Revue Scientifique Et Technique-Office International Des Epizooties, 28(1), 187-202. Published in final edited form as: Rev Sci Tech. 2009 April ; 28(1): 187-202.

Uğraş Dikmen A., Kına H.M., Özkan S.,\& İlhan M.N.( 2020). COVID-19 Epidemiyolojisi: Pandemiden Ne Öğrendik, J Biotechnol and Strategic Health Res. 2020;1(Özel Say1):29-36

DOI:10.34084/bshr.715153 https://dergipark.org.tr/en/download/article-file/1049524

Üstün, Ç v\& Özçiftçi, S. (2020). COVID-19 Pandemisinin Sosyal Yaşam ve Etik Düzlem Üzerine Etkileri: Bir Değerlendirme Çalışması, Anadolu Kliniği Tıp Bilimleri Dergisi, Ocak 2020; Cilt 25, Özel Say1 1,142-153 DOI: 10.21673/anadoluklin.721864

Verikios, G., Sullivan, M., Stojanovski, P., Giesecke, J., \& Woo, G. (2015). Assessing Regional Risks From Pandemic Influenza: A Scenario Analysis. The World Economy. S: 12251255 doi: $10.1111 /$ twec. 12296

WHO ( 2020). Rational use of personal protective equipment for coronavirus disease 2019 (COVID-19) Interim guidance 27 February 2020

Yetgin, M.A (2020) Koronavirüsün Borsa İstanbul'a Etkisi Üzerine Bir Araştırma Ve Stratejik Pandemi Yönetimi Finans Ekonomi ve Sosyal Araştırmalar Dergisi,5( 2): 324-335 ,DOI : 10.29106/fesa.736419 ISSN : $2602-2486$ 
Yılmaz, Ö.( 2017). 1847-1848 Kolera Salgını ve Osmanlı Coğrafyasındaki Etkileri, Avrasya İncelemeleri Dergisi,6( 1): 23-55 ISSN: 2147-0847 / E-ISSN: 2147-7469 DOI: $10.26650 / \mathrm{jes} 371499$

Yın,Y ., \& Wunderınk ,R,G. ( 2018). MERS, SARS and other coronaviruses as causes of pneumonia 2017 Asian Pacific Society of Respirology,23, 130-137 doi: 10.1111/resp.13196

Zheng ,Y.Y., Ma,Y.T., Zhang,J.Y., Xie,X. ( 2020). COVID-19 and the cardiovascular system Nature Reviews | Cardiolog, volume 17 | May 2020 | 259-260 file:///C:/Users/Ng1/Downloads/s41569-020-0360-5.pdf

http://www.yeditepehastanesi.com.tr/koronavirus-pandemisi-ilk-degil erişim tarihi.14.9.2020

https://www.verianaliz.net/pandemi-tarihi-corona-covid19-veri-analizinfografik/\#endemianchor erişim tarihi.14.9.2020

https://iscidunyasi.com/kisisel-koruyucu-donanim-nedir/ (erişim tarihi10.09 2020)

World Health Organization 2018 , 14 erişim tarihi.14.9.2020

https://www.teb.org.tr. (erişim tarihi,16.09.2020). 